\title{
Homologous recombination deficiency in epithelial ovarian cancer
}

\author{
Thomas Bartl · Valentina Paspalj • Christoph Grimm
}

Received: 24 February 2020 / Accepted: 31 March 2020 / Published online: 21 April 2020

(C) The Author(s) 2020

\begin{abstract}
Summary Since the introduction of poly-ADP-ribose polymerase (PARP) inhibitor therapy for epithelial ovarian cancer (EOC) patients, testing for aberrations of homologous recombination (HR) repair as a predictive biomarker of therapy response has become an area of particular clinical interest. As HR represents a crucial repair pathway of otherwise possibly lethal DNA double strand breaks, its deficiency triggers a phenotypic behavior of tumor cells resulting in the accumulation of genetic damage. PARP inhibitors target this emerging genomic instability by fostering DNA strand breaks. Whereas testing for mutations of the tumor-suppressor genes BRCA 1 and BRCA 2 as a pivotal part of the HR apparatus has entered clinical routine, approximately 30\% more high-grade EOC patients harbor aberrations of the HR pathway other than BRCA mutations and may therefore respond to PARP inhibition therapy. In recent years, several double-blind, placebo-controlled trials investigating sizeable patient cohorts have reported positive results of PARP inhibitor therapy response in HR-positive patient subgroups. Therefore, introducing HR testing in both the primary and recurrent setting as a biomarker for PARP inhibitor response may expand the range of patients who may profit from this therapeutic option beyond BRCA-mutated tumors.
\end{abstract}

Keywords Ovarian cancer · PARP inhibitor . Homologous recombination · Double strand break

\footnotetext{
T. Bartl · V. Paspalj · C. Grimm ( $ه)$

Department of Obstetrics and Gynecology, Division of General Gynecology and Gynecologic Oncology, Medical University of Vienna, Waehringer Guertel 18-20, 1090 Vienna, Austria

christoph.grimm@meduniwien.ac.at

T. Bartl

thomas.bartl@meduniwien.ac.at
}

\author{
Abbreviations \\ DSB Double strand breaks \\ EOC Epithelial ovarian cancer \\ HR Homologous recombination repair \\ HRd Homologous recombination repair deficient \\ PARP Poly-ADP-ribose polymerase \\ PFS Progression-free survival
}

\section{Rationale of homologous repair deficiency in epithelial ovarian cancer}

DNA double strand breaks (DSB) are considered to be among the most cytotoxic DNA lesions, triggering chromosomal aberration and ultimately cell death if not adequately repaired. The ability to restore DSBs depends on the activity of the homologous recombination repair (HR) apparatus, which copies the respective undamaged, homologous DNA of the sister chromatid to reconstruct the corrupted double strand during S and G2 phase. The functionality of this apparatus relies on the interaction of a complex set of proteins, such as the gene products of BRCA 1, BRCA 2 and $R A D 51$, among others. Any dysfunctional protein involved may induce phenotypical HR deficiency, as around $20 \%$ of all high-grade serous epithelial ovarian cancers (EOC) are observed to harbor a BRCA 1 or $B R C A 2$ germline or somatic mutation. Approximately $30 \%$ more, however, show BRCA wild-type status, but are associated with alterations of the HR apparatus which result in the phenotypical deficient cell behavior [1]. If HR fails, the process is ended by socalled non-homologous end joining, an error-prone process of random end-to-end fusion of damaged strands, leading to information loss and subsequently genomic instability. HR deficient (HRd) cells refer DSBs to non-homologous end joining more often and are therefore more likely to suffer fatal DNA damage. Introduction of poly-ADP-ribose polymerase (PARP) 
Table 1 Recent clinical trials assessing homologous recombination deficiency in ovarian cancer

\begin{tabular}{|c|c|c|c|c|c|c|}
\hline Author & Study name & Agent & Phase/Size & Patient cohort & $\begin{array}{l}\text { BRCAm tumors } \\
\text { treatment vs. placebo } \\
\text { PFS (months, } 95 \% \mathrm{Cl} \text { ) }\end{array}$ & $\begin{array}{l}\text { HRd tumors } \\
\text { treatment vs. placebo } \\
\text { PFS (months, } 95 \% \mathrm{Cl} \text { ) }\end{array}$ \\
\hline $\begin{array}{l}\text { Coleman et al. } \\
\text { (2017) [8] }\end{array}$ & ARIEL-3 & $\begin{array}{l}\text { Rucaparib } \\
600 \mathrm{mg} \text { BID }\end{array}$ & $\begin{array}{l}\text { Phase III } \\
n=564\end{array}$ & $\begin{array}{l}\text { Recurrent disease, } \\
\text { platinum sensitive }\end{array}$ & $\begin{array}{l}16.6 \text { vs. } 5.4 \text { months }^{a} \\
\text { HR } 0.23(0.16-0.34)\end{array}$ & $\begin{array}{l}13.6 \text { vs. } 5.4 \text { months }^{c} \\
\text { HR } 0.32(0.24-0.42)\end{array}$ \\
\hline $\begin{array}{l}\text { Mirza et al. (2016) } \\
\text { [9] }\end{array}$ & NOVA & $\begin{array}{l}\text { Niraparib } \\
300 \text { mg qDay }\end{array}$ & $\begin{array}{l}\text { Phase III } \\
n=553\end{array}$ & $\begin{array}{l}\text { Recurrent disease, } \\
\text { platinum sensitive }\end{array}$ & $\begin{array}{l}21.0 \text { vs. } 5.5 \text { months }^{b} \\
\text { HR } 0.27(0.17-0.41)\end{array}$ & $\begin{array}{l}12.9 \text { vs. } 3.8 \text { months }^{\mathrm{e}} \\
\text { HR } 0.38(0.24-0.59)\end{array}$ \\
\hline $\begin{array}{l}\text { Ray-Coquard et al. } \\
(2019) \text { [13] }\end{array}$ & PAOLA-1 & $\begin{array}{l}\text { Olaparib } \\
300 \mathrm{mg} \\
\text { BID + bevacizumab } \\
15 \mathrm{mg} / \mathrm{kg} \text { qw3 }\end{array}$ & $\begin{array}{l}\text { Phase III } \\
n=806\end{array}$ & $\begin{array}{l}\text { First line, platinum } \\
\text { sensitive }\end{array}$ & $\begin{array}{l}37.2 \text { vs. } 21.7 \text { months }^{\mathrm{a}} \\
\text { HR } 0.31(0.20-0.47)\end{array}$ & $\begin{array}{l}37.2 \text { vs. } 17.7 \text { months }^{a} \\
\text { HR } 0.33(0.25-0.45)\end{array}$ \\
\hline $\begin{array}{l}\text { González-Martín } \\
\text { et al. (2019) [11] }\end{array}$ & $\begin{array}{l}\text { PRIMA } \\
\text { ENGOT-0V26 } \\
\text { G0G-3012 }\end{array}$ & $\begin{array}{l}\text { Niraparib } \\
300 \text { mg qDay }\end{array}$ & $\begin{array}{l}\text { Phase III } \\
n=733\end{array}$ & $\begin{array}{l}\text { First line, platinum } \\
\text { sensitive }\end{array}$ & $\begin{array}{l}19.6 \text { vs. } 8.2 \text { months }^{a} \\
\text { HR } 0.50(0.31-0.83)\end{array}$ & $\begin{array}{l}22.1 \text { vs. } 10.9 \text { months }^{d} \\
\text { HR } 0.40(0.27-0.62)\end{array}$ \\
\hline $\begin{array}{l}\text { Coleman et al. } \\
\text { (2019) [12] }\end{array}$ & $\begin{array}{l}\text { VELIA } \\
\text { GOG-3005 }\end{array}$ & $\begin{array}{l}\text { Veliparib } \\
\text { 150/300/400 mg BID }\end{array}$ & $\begin{array}{l}\text { Phase III } \\
n=1140\end{array}$ & First line & $\begin{array}{l}34.7 \text { vs. } 22.0 \text { months }^{\mathrm{a}} \\
\text { HR } 0.44(0.28-0.68)\end{array}$ & $\begin{array}{l}31.9 \text { vs. } 20.5 \text { months }^{d} \\
\text { HR } 0.57(0.43-0.76)\end{array}$ \\
\hline \multicolumn{7}{|c|}{$\begin{array}{l}\text { BRCAm BRCA mutated, } H R(95 \% \mathrm{Cl}) \text { hazard ratio ( } 95 \% \text { confidence interval), } H R d \text { homologous recombination repair deficient, } P F S \text { progres } \\
\text { aBRCAm was defined as a detected germline or somatic mutation of the BRCA } 1 \text { and/or BRCA } 2 \text { gene } \\
\text { bBRCAm was defined as a BRCA } 1 \text { and/or } 2 \text { germline mutation } \\
\text { chRd was defined as a detection of a whole-genome loss of heterozygosity of at least } 16 \% \text { in a next-generation sequencing assay } \\
\text { dHRd was defined as a tumor score of } \geq 42 \text { on the myChoice HRD Plus assay (Myriad Genetics) and/or BRCA tumor or germline mutation } \\
\text { eHRd was defined as a tumor score of } \geq 42 \text { on the myChoice HRD Plus assay (Myriad Genetics) and and/or BRCA tumor mutation }\end{array}$} \\
\hline
\end{tabular}

inhibitors rendered HR repair both a possible target and biomarker in the treatment of EOC. As HRd cancer cells are more sensitive to lesser DNA damages favoring subsequent DSBs, PARP inhibition-induced excess of single strand breaks leads to accumulation of DSB HRd tumor cells cannot repair [2].

\section{Defining and diagnosing homologous recombination deficiency}

Whereas testing BRCA mutation status as a predictive biomarker for response to PARP inhibition has entered clinical routine, selecting BRCA wildtype patients who express an HRd phenotype poses a clinical challenge. Sometimes termed BRCAness, manifold steps of the HR pathway apart from BRCA mutations may contribute to its deficiency and therefore have to be considered for testing. Three methodically different approaches to test for HR deficiency have been proposed to date:

First, "genomic scarring" assays aim to quantify large genomic aberrations by next generation whole genome sequencing. Whereas the "CDx BRCA LOH" (Foundation Medicine, Cambridge, MA, USA) detects the percentage of loss of heterozygosity throughout the genome as well as mutations in BRCA 1 or BRCA 2, the "myChoice" HR deficiency test (Myriad Genetics Inc., Salt Lake City, UT, USA) calculates a score based on the presence of loss of heterozygosity, large scale transitions, telomeric allelic imbalance. All trials depicted in Table 1 relied on genomic scarring assays [3]. Second, big data analyses of somatic point mutations and large-scale genomic alterations allow for the definition of gene signatures characteristic for HRd carcinoma. The so-called HRDetect test was designed upon such gene signature analyses and thereby detects $B R C A$ pathway-related HRd tumors with high sensitivity [4]. Third, assessing point mutations in HR deficiency-related genes using DNA sequencing panels combined with immunostaining of respective genes may be predictive for HR deficiency, e.g. RAD51 expression as a crucial step of HR. Approaches solely depicting BRCA pathway-related HR deficiency, however, may be of limited clinical applicability since they may fail to identify tumors with functional mutations in other HR deficiency-related genes, such as ATM, CHEK and ATR [5].

Whereas several approaches of detecting HR deficiency are available, no specific assay may be generally recommended since all proposed methods lack broad prospective validation. Advantages and limitations of each assay should be considered carefully according to the specific clinical question and the framework conditions of the respective center.

\section{Recent clinical trials assessing homologous recombination deficiency in ovarian cancer}

As depicted in Table 1, several prospective trials evaluating clinical efficacy of PARP inhibitors in sizeable cohorts provide evidence on survival benefits for progression-free survival (PFS) in patients with HRd EOC in both the first-line and recurrent setting. Heterogeneous definitions of HR deficiency, BRCA-mutated study subgroups and different methods of HR deficiency assessment pose a challenge if study results are to be compared directly or translated into clinical practice. Other large trials evaluating PARP inhibitor efficacy such as SOLO-2 or Study 19 did not assess HR deficiency and were therefore not considered for the present review $[6,7]$.

The ARIEL-3 trial, a phase 3 , randomized, doubleblind study of rucaparib $600 \mathrm{mg}$ BID maintenance in a cohort of 564 patients with recurrent, platinum 
sensitive high-grade serous or endometroid EOC observed a significantly increased PFS of 13.6 months for patients with HRd tumors in the treatment arm versus 5.4 months in the placebo arm (HR 0.32; 95\% CI 0.24-0.42). In patients with BRCA-mutated tumors, PFS was 16.6 months in the treatment arm versus 5.4 months in the placebo arm (HR 0.23; 95\%CI 0.16-0.34) [8].

This result was supported by the NOVA trial, a phase 3, randomized, double-blind study of niraparib $300 \mathrm{mg}$ daily maintenance in a cohort of 553 patients with platinum sensitive high-grade serous EOC. For patients with HRd but germline BRCA wildtype tumors, authors reported a PFS of 12.9 months in the treatment arm compared to 3.8 months in the placebo arm (HR 0.38; 95\%CI 0.24-0.59). In patients with BRCA germline-mutated tumors PFS was 21.0 months in the treatment arm versus 5.5 months in the placebo arm (HR 0.27; 95\% CI 0.17-0.41) [9].

The QUADRA trial, a phase 2, single-arm study of niraparib $300 \mathrm{mg}$ daily monotherapy in a cohort of 463 patients with platinum-sensitive high-grade serous EOC who received at least three prior lines of chemotherapy observed a median overall survival of 26.0 months (18.1-not estimable) in patients with BRCA-mutated tumors, 19.0 months (14.5-24.6) in patients with HRd tumors and 15.5 months (11.6-19.0) in HR proficient tumors, indicating HR deficiency to maintain its predictive value for response in heavily pretreated patients [10].

To date, three trials reported positive results for olaparib, niraparib, and veliparib in first-line maintenance therapy:

The PRIMA trial, a phase 3 , randomized, doubleblind study of $300 \mathrm{mg}$ niraparib daily maintenance versus placebo in a cohort of 733 patients with response to first-line platinum-based chemotherapy for advanced high-grade serous or endometroid EOC observed a PFS of 22.1 months in patients with HRd tumors in the treatment arm versus 10.9 months in the placebo arm (HR 0.40; 95\%CI 0.27-0.62). In patients with BRCA-mutated tumors, PFS was 19.6 months in the treatment arm versus 8.2 months in the placebo arm (HR 0.50; 95\%CI 0.31-0.83) [11].

The VELIA trial, a phase 3 , randomized, doubleblind study of veliparib $400 \mathrm{mg}$ twice daily maintenance versus placebo in a cohort of 1140 patients with response to first-line platinum-based chemotherapy for advanced high-grade serous EOC observed a PFS of 31.9 months in patients with HRd tumors in the treatment arm versus 20.5 months in the placebo arm (HR 0.57; 95\%CI 0.43-0.76). In the BRCA mutated cohort, PFS was 34.7 months in the treatment arm versus 22.0 months in the placebo arm (HR 0.44; 95\%CI 0.28-0.68) [12].

The PAOLA-1 trial, a phase 3, randomized, double-blind study of a combinatory olaparib $300 \mathrm{mg}$ twice daily versus placebo and bevacizumab $15 \mathrm{mg} / \mathrm{kg}$ q3weeks maintenance therapy in a cohort of 806 patients with response to first-line platinum-based chemotherapy for advanced platinum-sensitive highgrade serous EOC reported in patients with HRd tumors a PFS of 37.2 months in the olaparib arm compared to 17.7 months in the control arm (HR 0.38; 95\% CI 0.24-0.45). In patients with BRCA-mutated tumors, PFS was 37.2 months in the treatment arm versus 21.7 months in the placebo arm (HR 0.31; 95\%CI 0.20-0.47) [13].

Of note, no clinical evidence exists for PARP inhibitor therapy in other histologic EOC subtypes to date. Since associated by different driver mutations and rarely harboring HR deficiency, they were not included into recent studies for PARP inhibitor efficacy $[14,15]$.

HR deficiency testing appears to be a promising predictive biomarker for the efficacy of PARP inhibitor therapy in high-grade serous EOC patients in the firstline and recurrent setting. Since patients without HRd tumors also seem to benefit from PARP inhibition to some extent, it may be assumed that HRd assays lack accuracy or do not depict certain tumors with non $B R C A$ pathway-related HRd phenotypes [11]. Nevertheless, introducing HRd testing in addition to $B R C A$ mutation analysis for both primary and recurrent therapy may thereby aid greatly to select patients who will most likely profit from PARP inhibitor therapy.

\section{Future prospects of PARP inhibitor combination trials}

The combined use of PARP inhibitors with other active agents is of increasing interest in the treatment of EOC. Relating to the positive results of the PAOLA-1 trial, it has been hypothesized that antiangiogenic agents induce a hypoxic environment, resulting in down-regulation of genes of HR [16, 17]. Thereby, tumor cells otherwise not sensitive to PARP inhibition could be sensitized and a synergistic activity could be exploited. Particularly, the oral VEGF inhibitor cediranib showed promising results in a 2019 phase II study by Liu et al. [18]. A combination of $30 \mathrm{mg}$ cediranib daily with $200 \mathrm{mg}$ olaparib twice daily compared to $400 \mathrm{mg}$ olaparib twice daily only in relapsed platinum-sensitive ovarian cancer including 90 patients reported significant prolonged overall survival of 37.8 versus 23.0 months in patients with BRCAmutated tumors. However, no HRd subgroup analysis has been published to date. To address this question, the phase III trial ICON-9 (NCT03278717) is currently evaluating a combination of cediranib with olaparib in relapsed platinum-sensitive ovarian cancer. Final results, however, are not expected before the year 2023.

\section{Take home message}

HR deficiency defines a subset of high-grade serous EOC patients who are most likely to benefit from PARP 
inhibitor therapy in the first-line and recurrent setting. Thereby, the scope of targeting solely BRCA-mutated tumors may be expanded significantly to approximately $50 \%$ of all high-grade EOC patients. Whereas different approaches of testing for HR deficiency are available to date, further research will be necessary to improve HR assay accuracy. Moreover, combining PARP inhibitors with antiangiogenic agents seems to be a promising concept which may expand the indication of PARP inhibition even beyond current HR deficiency.

Funding Open access funding provided by Medical University of Vienna.

Conflict of interest C. Grimm received consultant fees from AstraZeneca, Celgene, MSD, PharmaMar, Roche, GSK/Tesaro, Vifor Pharma and Clovis, compensation for lecturing activities from Amgen, AstraZeneca, MSD, PharmaMar, Roche, GSK/ Tesaro and direct research funding: Meda Pharma, Roche Diagnostics. The disclosed funding is not related to the research reported. T. Bartl and V. Paspalj declare that they have no competing interests.

Open Access This article is licensed under a Creative Commons Attribution 4.0 International License, which permits use, sharing, adaptation, distribution and reproduction in any medium or format, as long as you give appropriate credit to the original author(s) and the source, provide a link to the Creative Commons licence, and indicate if changes were made. The images or other third party material in this article are included in the article's Creative Commons licence, unless indicated otherwise in a credit line to the material. If material is not included in the article's Creative Commons licence and your intended use is not permitted by statutory regulation or exceeds the permitted use, you will need to obtain permission directly from the copyright holder. To view a copy of this licence, visit http://creativecommons.org/licenses/by/4.0/.

\section{References}

1. Ledermann JA, Drew Y, Kristeleit RS. Homologous recombination deficiency and ovarian cancer. Eur J Cancer. 2016;60:49-58.

2. Yates MS, Timms K, Daniels MS, Oakley HD, Munsell MF, LanchburyJS, etal. Evaluation of BRCA1/2 andhomologous recombination defects in ovarian cancer and impact on clinical outcomes. JClin Oncol. 2017;35(15_suppl):5511.

3. Watkins JA, Irshad S, Grigoriadis A, TuttANJ. Genomic scars as biomarkers of homologous recombination deficiency and drug response in breast and ovarian cancers. Breast Cancer Res. 2014;16(3):211.

4. Alexandrov LB, Nik-Zainal S, Wedge DC, Aparicio SAJR, Behjati S, Biankin AV, et al. Signatures of mutational processes in human cancer. Nature. 2013;500(7463):415-21.

5. Pellegrino B, Mateo J, Serra V, Balmaña J. Controversies in oncology: are genomic tests quantifying homologous recombination repair deficiency (HRD) usefulfor treatment decision making? ESMO Open. 2019;4(2):e480.

6. Pujade-Lauraine E, Ledermann JA, Selle F, Gebski V, Penson RT, Oza AM, et al. Olaparib tablets as maintenance therapy in patients with platinum-sensitive, relapsed ovarian cancer and a BRCA1/2 mutation (SOLO2/ENGOT-Ov21): a double-blind, randomised, placebo-controlled, phase 3 trial. Lancet Oncol. 2017;18(9):1274-84.

7. Morgan RD, Clamp AR, Evans DGR, Edmondson RJ, Jayson GC. PARP inhibitors in platinum-sensitive high- grade serous ovarian cancer. Cancer Chemother Pharmacol. 2018;81(4):647-58.

8. Coleman RL, Oza AM, Lorusso D, Aghajanian C, Oaknin A, Dean A, et al. Rucaparib maintenance treatment for recurrent ovarian carcinoma after response to platinum therapy (ARIEL3): a randomised, double-blind, placebocontrolled, phase 3 trial. Lancet. 2017;390(10106):1949-61.

9. Mirza MR, Monk BJ, Herrstedt J, Oza AM, Mahner S, Redondo A, et al. Niraparib maintenance therapy in platinum-sensitive, recurrent ovarian cancer. N Engl J Med. 2016;375(22):2154-64.

10. Moore KN, SecordAA, Geller MA, Miller DS, Cloven N, Fleming GF, et al. Niraparib monotherapy for late-line treatment of ovarian cancer (QUADRA): a multicentre, open-label, single-arm, phase 2 trial. Lancet Oncol. 2019;20(5):636-48.

11. Gonzalez-Martin A, Pothuri B, Vergote I, DePont Christensen R, Graybill W, Mirza MR, et al. Niraparib in Patients with Newly Diagnosed Advanced Ovarian Cancer. N Engl J Med. 2019;381(25):2391-402.

12. Coleman RL, Fleming GF, Brady MF, Swisher EM, Steffensen KD, Friedlander M, et al. Veliparib with first-line chemotherapy and as maintenance therapy in ovarian cancer. NEngl J Med. 2019;381(25):2403-15.

13. Ray-Coquard I, Pautier P, Pignata S, Perol D, GonzalezMartin A, Berger R, et al. Olaparib plus bevacizumab as first-line maintenance in ovarian cancer. N Engl J Med. 2019;381(25):2416-28.

14. Gorringe KL, Cheasley D, Wakefield MJ, Ryland GL, Allan PE, Alsop K, Amarasinghe KC, Ananda S, Bowtell DDL, Christie M, Chiew YE, Churchman M, DeFazio A, Fereday S, Gilks CB, Gourley C, Hadley AM, Hendley J, Hunter SM, Kaufmann SH, Kennedy CJ, Köbel M, Le Page C, Li J, Lupat R, McNally OM, McAlpine JN, Pyman J, Rowley SM, Salazar C, Saunders H, Semple T, Stephens AN, Thio N, Torres MC, Traficante N, Zethoven M, Antill YC, Campbell IG, Scott CL. Therapeutic options for mucinous ovarian carcinoma. Gynecol Oncol. 2020 Mar;156(3):552-560. https://doi.org/ 10.1016/j.ygyno.2019.12.015. Epub 2020 Jan 2. PubMed PMID:31902686; PubMedCentral PMCID: PMC7056511.

15. Sugino K, Tamura R, Nakaoka H, Yachida N, Yamaguchi M, Mori Y, et al. Germline and somatic mutations of homologous recombination-associated genes in Japanese ovarian cancer patients. Sci Rep. 2019;9(1):17808.

16. Bindra RS, Gibson SL, Meng A, Westermark U, Jasin M, PierceAJ, etal. Hypoxia-induced down-regulation ofBRCA1 expression by E2Fs. Cancer Res. 2005;65(24):11597-604.

17. Chan N,BristowRG. "Contextual" syntheticlethality and/or loss of heterozygosity: tumor hypoxia and modification of DNA repair. Clin Cancer Res. 2010;16(18):4553-60.

18. Liu JF, Barry WT, Birrer M, Lee JM, Buckanovich RJ, Fleming GF, et al. Overall survival and updated progressionfree survival outcomes in a randomized phase II study of combination cediranib and olaparib versus olaparib in relapsed platinum-sensitive ovarian cancer. Ann Oncol. 2019;30(4):551-7.

Publisher's Note Springer Nature remains neutral with regard to jurisdictional claims in published maps and institutional affiliations. 